\title{
Phytoprotection
}

\section{Note on the effect of low temperatures on the survival of immature stages of the rusty grain beetle, Cryptolestes ferrugineus}

\section{P.S. Barker}

Volume 71, numéro 1, 1990

URI : https://id.erudit.org/iderudit/705981ar

DOI : https://doi.org/10.7202/705981ar

Aller au sommaire du numéro

Éditeur(s)

Société de protection des plantes du Québec (SPPQ)l

ISSN

0031-9511 (imprimé)

1710-1603 (numérique)

Découvrir la revue

Citer cet article

Barker, P. (1990). Note on the effect of low temperatures on the survival of immature stages of the rusty grain beetle, Cryptolestes ferrugineus.

Phytoprotection, 71(1), 37-39. https://doi.org/10.7202/705981ar
Résumé de l'article

Du blé infesté de cucujide roux (Cryptolestes ferrugineus) a été exposé pendant quelques semaines à $-5^{\circ}, 0^{\circ}, 5^{\circ}, 10^{\circ}$ ou $15^{\circ} \mathrm{C}$. On a observé une réduction de la survie des stades immatures (oeufs, larves et pupes) à toutes les températures. Les valeurs de TL50 et de TL99 ont été calculées pour chaque température, à l'exception du traitement à $-5^{\circ} \mathrm{C}$ pour lequel la mortalité était de $100 \%$ en moins de 2 semaines. 


\title{
Note on the effect of low temperatures on the survival of immature stages of the rusty grain beetle, Cryptolestes ferrugineus
}

\author{
P.S. Barker \\ Research Station, Agriculture Canada, 195 Dafoe Road, \\ Winnipeg, Manitoba, Canada R3T 2M9. Contribution No. 1344
}

(Received 1989-05-31; accepted 1989-11-24)

\begin{abstract}
Wheat infested with the rusty grain beetle (Cryptolestes ferrugineus) was held for varying numbers of weeks at temperatures of $-5^{\circ}, 0^{\circ}, 5^{\circ}, 10^{\circ}$, and $15^{\circ} \mathrm{C}$ in separate tests. Survival of the immature stages (eggs, larvae and pupae) of the beetle declined each week at each temperature. The $\mathrm{LT}_{50}$ and $\mathrm{LT}_{99}$ were determined for each of the temperatures except for $-5^{\circ} \mathrm{C}$ where $100 \%$ mortality was observed in a 1 - to 2 -week period of exposure.
\end{abstract}

Barker, P.S. 1990. Note on the effect of low temperatures on the survival of immature stages of the rusty grain beetle, Cryptolestes ferrugineus. PHYTOPROTECTION 71 : 37-39.

Du blé infesté de cucujide roux (Cryptolestes ferrugineus) a été exposé pendant quelques semaines à $-5^{\circ}, 0^{\circ}$, $5^{\circ}, 10^{\circ}$ ou $15^{\circ} \mathrm{C}$. On a observé une réduction de la survie des stades immatures (oeufs, larves et pupes) à toutes les températures. Les valeurs de $\mathrm{TL}_{50}$ et de $\mathrm{TL}_{99}$ ont été calculées pour chaque température, à l'exception du traitement à $-5^{\circ} \mathrm{C}$ pour lequel la mortalité était de $100 \%$ en moins de 2 semaines.

The cooling of bulk grain and oilseeds has been recommended to prevent spoilage by insects and molds by eliminating hot-spots and halting the increase of insect populations. This cooling can be achieved by forcing cold winter air through bulk stored crops (Loschiavo et al. 1983). Watters (1963) showed that the transfer and turning of bulks of grain at intervals during 2 days of cold weather $\left(-6.7\right.$ to $\left.+4.4^{\circ} \mathrm{C}\right)$ reduced the average temperature of a bulk of wheat (Triticum aestivum L.) from $12.2^{\circ}$ to $6.6^{\circ} \mathrm{C}$. Smith (1970) found that the center of a 27.2 metric tonne bulk of wheat would cool naturally to temperatures below $0^{\circ} \mathrm{C}$ during 20 weeks of Manitoba's winter. The rusty grain beetle (Cryptolestes ferrugineus [Stephens]) cannot complete its development at temperatures of $17.5^{\circ} \mathrm{C}$ or less (Smith 1965), but can become coldacclimated and survive prolonged exposure to freezing temperatures if subjected to slowly declining temperatures. Smith (1970) found that non-acclimated larvae are very susceptible to temperatures of $2^{\circ}$, $-6^{\circ}$, and $-12^{\circ} \mathrm{C}$, but did not describe the effects of low temperatures between $2^{\circ} \mathrm{C}$ and the adult acclimation temperature of $15^{\circ} \mathrm{C}$ on the larvae. The aim of this work

$\overline{0031-9511 / 90} \$ 1.00+.10$ was to ascertain the effect of low temperatures of -5 to $15^{\circ} \mathrm{C}$ on the survival of the immature stages of the rusty grain beetle.

Two hundred flakes of wheat germ, each containing a single egg of $C$. ferrugineus were placed individually in glass cells made from hanging drop slides and cover slips. Cover slips were fastened to the slides with cut down hairpins. These slides were placed in a desiccator and incubated at $30 \pm 1{ }^{\circ} \mathrm{C}$ and $75 \pm 5 \%$ RH. After 5 weeks, each slide was examined under a dissection microscope to determine if live beetles had emerged.

Thriving six-week-old cultures of rusty grain beetles in hard red spring wheat $(16 \%$ moisture content) were kept at $30 \pm 1{ }^{\circ} \mathrm{C}$ and $75 \pm 5 \% \mathrm{RH}$. Cultures were mixed before use. One hundred and fifty $\mathrm{mL}$ of culture were placed in each of 32 jars $(0.5 \mathrm{~L})$ for each test. There were four replicates of seven exposure periods plus the untreated controls (kept at $31^{\circ} \mathrm{C}$ ) for each low temperature. The exposure periods were $1,2,3,4,9,10$, and 12 weeks at each temperature. The temperatures for the tests were $-5,0^{\circ}, 5^{\circ}, 10^{\circ}$, and $15^{\circ} \mathrm{C}$. Three days after the start of each test, adults were removed from the treatments and controls by sieving the grain. The grain with the immature insects inside the kernels was returned to the respective jars at the original 
experimental temperature. At the end of each exposure period, four treatment jars were moved from the test temperature and placed at $30 \pm 1{ }^{\circ} \mathrm{C}$ and $75 \pm 5 \% \mathrm{RH}$. After four weeks the grain from each jar was sieved and the number of beetles found were recorded. Control jars were not incubated at low temperatures but placed at $30 \pm 1{ }^{\circ} \mathrm{C}$ and $75 \pm 5 \% \mathrm{RH}$ for 4 weeks after which the number of adult beetles were recorded. Mortality during low temperature incubation was calculated as the difference between the numbers of adults emerging in the treated jars and the number emerging in the controls. One hundred kernels were taken from the original cultures before the grain was placed in the jars and dissected under a low power microscope. All stages of development of the rusty grain beetle were present in the grain.

Probit analyses and tests for parallelism and potency ratios were performed on the mortality data obtained (Bliss 1935; Finney 1971).

Mortality during development of the insects on wheat germ in hanging drop glass cells averaged $12.2 \%$. This mortality rate of $12 \%$ was similar to that reported by Smith (1965) and was used to correct for mortality in the untreated grain controls before use of Abbott's (1925) formula in the probit analyses (Bliss 1935; Finney 1971). The total numbers of insects recovered from the controls after incubation of the grain were 166 , 460,992 , and 862 beetles at $0^{\circ}, 5^{\circ}, 10^{\circ}$, and $15^{\circ} \mathrm{C}$, respectively.
The times required to obtain 50 and $99 \%$ mortality $\left(\mathrm{LT}_{50}\right.$ and $\left.\mathrm{LT}_{99}\right)$ of the immature stages of laboratory-reared rusty grain beetles when subjected to temperatures of $0^{\circ}$, $5^{\circ}, 10^{\circ}$, and $15^{\circ} \mathrm{C}$ were determined (Table 1). At $-5^{\circ} \mathrm{C}$ only $4.9 \%$ of the immature stages survived for 1 week and none survived after 2 weeks at this temperature, confirming the results obtained by Smith (1970) at $-6^{\circ} \mathrm{C}$ for non-acclimated beetles.

Mortality of the immature stages increased with time at all temperatures (Table 1), including $15^{\circ} \mathrm{C}$ (slopes of probit lines were positive). There was also a progressive increase in the median lethal time $\left(\mathrm{LT}_{50}\right)$ as temperatures rose from $0^{\circ}$ to $15^{\circ} \mathrm{C}$. Mortality of immature stages at $15^{\circ} \mathrm{C}$ was unexpected because Smith (1970) acclimated rusty grain beetles at $15^{\circ} \mathrm{C}$ to get them to survive long exposures at $-6^{\circ}$ and $-12^{\circ} \mathrm{C}$. The immature stages do not become acclimated, but die at temperatures of $15^{\circ} \mathrm{C}$ or less, thus offering an opportunity for a practical, non-toxic, method of control of this species. Control should include two steps : one which cools the grain to temperatures below $10^{\circ} \mathrm{C}$ to kill the immature stages, and the second in which adult beetles are removed from the grain, possibly by sieving methods.

The $\mathrm{LT}_{50}$ was lower at $0^{\circ} \mathrm{C}$ than at $5^{\circ}$, $10^{\circ}$, or $15^{\circ} \mathrm{C}$ (Table 1 ). Table 2 shows the ratios between the $\mathrm{LT}_{50}$ obtained at the different temperatures and the potency ratios that were calculated assuming parallelism of the probit lines. There was no conflict with the hypothesis of parallelism only

Table 1. The effect of time of exposure at four temperatures on the mortality of the immature stages of the rusty grain beetle $\S$

\begin{tabular}{|c|c|c|c|c|c|}
\hline $\begin{array}{c}\text { Temperature } \\
\left({ }^{\circ} \mathrm{C}\right)\end{array}$ & $\begin{array}{c}\mathrm{LT}_{50} \\
\text { (weeks) }\end{array}$ & $\begin{array}{c}\mathrm{LT}_{99} \\
\text { (weeks) }\end{array}$ & $\begin{array}{l}\text { Heterogeneity } \\
\text { factor }\end{array}$ & Slope & Intercept \\
\hline 0 & $\begin{array}{c}1.4 \\
(0.9-2.2) \dagger\end{array}$ & $\begin{array}{c}4.3 \\
(1.6-11.8)\end{array}$ & 0.1 & 4.9 & 4.1 \\
\hline 5 & $\begin{array}{c}1.7 \\
(1.5-1.8)\end{array}$ & $\begin{array}{c}6.1 \\
(5.1-7.3)\end{array}$ & 1.2 & 4.2 & 3.9 \\
\hline 10 & $\begin{array}{c}1.7 \\
(1.5-1.9)\end{array}$ & $\begin{array}{c}47.8 \\
\left(35.6^{-64.3)}\right.\end{array}$ & 8.3 & 1.6 & 4.6 \\
\hline 15 & $\begin{array}{c}2.6 \\
(2.4-2.8)\end{array}$ & $\begin{array}{c}35.0 \\
(27.9-43.8)\end{array}$ & 5.6 & 2.1 & 4.1 \\
\hline
\end{tabular}

$\S$ Outputs from probit analysis.

+ Confidence interval at $95 \%$. 
Table 2. Potency ratios from comparisons of the $\mathrm{LT}_{50}$ obtained from exposure of immature Cryptolestes ferrugineus to different temperatures

\begin{tabular}{|c|c|c|c|}
\hline \multicolumn{2}{|c|}{$\begin{array}{l}\text { Comparison between } \\
\text { temperatures }\left({ }^{\circ} \mathrm{C}\right)\end{array}$} & \multirow{2}{*}{$\begin{array}{l}\text { Actual ratio } \\
\text { of } \mathrm{LT}_{50}\end{array}$} & \multirow{2}{*}{$\begin{array}{l}\text { Potency ration } \pm \text { variance at } \\
\text { the } \mathrm{LT}_{50} \text { assuming parallelism }\end{array}$} \\
\hline low & high & & \\
\hline 0 & $5^{\S}$ & 1.17 & $1.202 \pm 0.001$ \\
\hline 0 & 10 & 1.18 & $1.516 \pm 0.007$ \\
\hline 0 & 15 & 1.75 & $3.533 \pm 0.001$ \\
\hline 5 & 10 & 1.00 & $1.399 \pm 0.001$ \\
\hline 5 & 15 & 1.49 & $1.813 \pm 0.001$ \\
\hline 10 & 15 & 1.48 & $1.342 \pm 0.001$ \\
\hline
\end{tabular}

$\S$ No conflict with the hypothesis of parallelism $(P>0.1)$

for comparison of the probit lines obtained from the data of $0^{\circ}$ and $5^{\circ} \mathrm{C}$.

The times required to obtain $99 \%$ mortality $\left(\mathrm{LT}_{99}\right)$ at $0^{\circ} \mathrm{C}$ and $5^{\circ} \mathrm{C}$ were similar (4 to 6 weeks), as were the $\mathrm{LT}_{99}$ obtained at $10^{\circ}$ and $15^{\circ} \mathrm{C}$ ( 35 to 48 weeks). The slopes of the probit lines for $0^{\circ}$ and $5^{\circ} \mathrm{C}$ were steeper than those for $10^{\circ}$ and $15^{\circ} \mathrm{C}$. The high values of the $\mathrm{LT}_{99}$ for both $10^{\circ}$ and $15^{\circ} \mathrm{C}$ suggest that these temperatures may not be low enough, even for a very long period of exposure, to provide practical control of the immature stages of the rusty grain beetle. However, the lower temperatures of $0^{\circ}$ and $5^{\circ} \mathrm{C}$ might be adequate for beetle control, provided that the adults, which become acclimated, are removed from the grain, in some manner.

This work has shown that the immature stages of the rusty grain beetle will slowly succumb to temperatures of $15^{\circ} \mathrm{C}$ or less, and that in grain in experimental jars an effective kill of $99 \%$ can be obtained within 6 weeks at temperatures of $0^{\circ}$ and $5^{\circ} \mathrm{C}$.

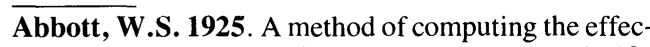
tiveness of an insecticide. J. Econ. Entomol. 18: 265-267.

Bliss, C.T. 1935. The calculation of the dosagemortality curve. Ann. Appl. Biol. 22: 134-167.

Finney, D.J. 1971. Probit analysis. $3^{\text {rd }}$ ed. Cambridge Univ. Press, $333 \mathrm{pp}$.

Loschiavo, S.R. (Editor), D. Abramson, P.S. Barker, S.R. Loschiavo, J.T. Mills, R.N. Sinha, L.B. Smith, F.L. Watters, and N.D.G. White. 1983. Insects, mites, and molds in farm-stored grain in the Prairie Provinces. Agric. Can. Publ. $1595 /$ E. 31 pp.

Smith, L.B. 1965. The intrinsic rate of natural increase of Cryptolestes ferrugineus (Stephens) (Coleoptera, Cucujidae). J. Stored Prod. Res. 1: 35-49.

Smith, L. 1970. Effects of cold-acclimation on supercooling and survival of the rusty grain beetle, Cryptolestes ferrugineus (Stephens) (Coleoptera: Cucujidae) at subzero temperatures. Can. J. Zool. 48: 853-858.

Watters, F.L. 1963. The cooling of heating grain by transfer during cold weather. J. Econ. Entomol. 56: 215-219. 